\title{
Vibrio casei sp. nov., isolated from the surfaces of two French red smear soft cheeses
}

Correspondence

Siegfried Scherer

siegfried.scherer@wzw.tum.de
Anne Bleicher, ${ }^{1}$ Klaus Neuhaus ${ }^{1}$ and Siegfried Scherer ${ }^{1,2}$

\author{
${ }^{1}$ Abteilung für Mikrobiologie, ZIEL, Technische Universität München, D-85354 Freising, Germany \\ ${ }^{2}$ Lehrstuhl für Mikrobielle Ökologie, Department für Grundlagen der Biowissenschaften, WZW, \\ Technische Universität München, D-85350 Freising, Germany
}

\begin{abstract}
Three Gram-negative, rod-shaped, catalase- and oxidase-positive, facultatively anaerobic and motile bacteria, strains WS 4538 , WS $4539^{\top}$ and WS 4540, were isolated from the surfaces of two fully ripened French red smear soft cheeses. Based on 16S rRNA gene sequence similarity, all three strains were shown to belong to the genus Vibrio. They are most closely related to Vibrio rumoiensis $\mathrm{S}-1^{\top}$ (96.3\% similarity) and Vibrio litoralis MANO22D ${ }^{\top}$ (95.9\%). DNA-DNA hybridization confirmed that all three isolates belong to the same species and clearly separated strain WS $4539^{\top}$ from $V$. rumoiensis DSM $19141^{\top}$ (38-42\% relatedness) and $V$. litoralis DSM $17657^{\top}(28-37 \%)$. In contrast to their nearest relatives, the strains exhibited $\beta$-galactosidase and aesculin hydrolase activities. A 14 bp insertion in the 16S rRNA gene sequence forms an elongated structure at helix 10 in the rRNA molecule and provides a tool for PCR-based identification of the novel species. Partial sequences of the housekeeping genes atp $A, \operatorname{rec} A, \operatorname{rpo} A$ and $\mathrm{pyr} H$ supported the conclusion that the three isolates constitute a separate species within the genus Vibrio. The name Vibrio casei sp. nov. is proposed for the novel taxon. Strain WS $4539^{\top}$ (=DSM $22364^{\top}=$ LMG $25240^{\top}$; DNA G $+\mathrm{C}$ content $\left.41.8 \mathrm{~mol} \%\right)$ is the type strain and WS 4540 (=DSM $22378=$ LMG 25241) is a reference strain.
\end{abstract}

The family Vibrionaceae (Baumann \& Schubert, 1984) belongs to the class Gammaproteobacteria and includes, amongst others, the genera Photobacterium (Baumann \& Baumann, 1984), Salinivibrio (Mellado et al., 1996) and Vibrio. At the time of writing, the genus Vibrio consists of 72 recognized species that form nine phylogenetically distinct clades (Association of Vibrio Biologists; http:// www.vibriobiology.net/). The clearly separated rumoiensis clade consists of Vibrio rumoiensis (Yumoto et al., 1999) and Vibrio litoralis (Nam et al., 2007) and forms a distant lineage within the genus. Micro-organisms belonging to the genus Vibrio are known to live either freely or associated as symbionts with aquatic animals in marine or estuarine waters (Browne-Silva \& Nishiguchi, 2008) or as parasites of fish, crustaceans and molluscs (Thompson et al., 2004). Vibrio species have been reported less frequently as members of microbial consortia on cheese

\footnotetext{
The GenBank/EMBL/DDBJ accession numbers for the 16S rRNA gene, atpA, recA, rpoA and pyrH gene sequences of strains WS $4539^{\top}$ and WS 4540 and V. litoralis DSM $17657^{\top}$ are FJ968710-FJ968723.

DNA-DNA hybridization results, detailed methods for phylogenetic analysis of housekeeping genes and the resulting trees and details of members of the Vibrionaceae showing a similar 16S rRNA gene insert to the novel strains and models of 16S rRNA secondary structure with and without the insert are available as supplementary material with the online version of this paper.
}

surfaces (Feurer et al., 2004), but some studies have suggested that they play a role in the ripening process (ElBaradei et al., 2007).

The composition of the surface microbial consortia of two French smear-ripened cheeses, Petit Munster Ermitage and Reflets de France Petit Livarot, was analysed using Fouriertransform infrared (FT-IR) spectroscopy (Kümmerle et al., 1998; Naumann et al., 1991). After 5 days of aerobic incubation at $10-30{ }^{\circ} \mathrm{C}$, isolates were picked randomly from fully grown plate count agar plates, supplemented with $3 \% \mathrm{NaCl}(\mathrm{PC} 3+)$. The cell densities of the surface consortia were $6 \times 10^{9}$ c.f.u. $\mathrm{ml}^{-1}$ (Munster) and $4 \times 10^{10}$ c.f.u. $\mathrm{ml}^{-1}$ (Livarot). Strains WS 4538 and WS $4539^{\mathrm{T}}$ were isolated from the Munster cheese at the Fromagerie de l'Ermitage, Bulgnéville, France ( $\left.48^{\circ} 12^{\prime} 16^{\prime \prime} \mathrm{N} 5^{\circ} 49^{\prime} 17^{\prime \prime} \mathrm{E}\right)$, and strain WS 4540 was isolated from the Livarot cheese at Les Fromages de Tradition, Mondeville, France $\left(49^{\circ} 10^{\prime} 31^{\prime \prime}\right.$ $\left.\mathrm{N} 0^{\circ} 19^{\prime} 22^{\prime \prime} \mathrm{W}\right)$. The novel species represented by the isolated strains was estimated to contribute approximately $10^{8}$ c.f.u. $\mathrm{ml}^{-1}$ to the surface consortia of the two cheeses.

Unless otherwise stated, cells were cultured in marine broth (MB; Difco) at $30{ }^{\circ} \mathrm{C}$ with shaking at 180 r.p.m. All experiments were conducted at least twice. Tolerance towards temperature $\left(2,4,10,14,30,37\right.$ and $\left.43{ }^{\circ} \mathrm{C}\right)$ was recorded for 5 days. Growth occurred between 2 and $30{ }^{\circ} \mathrm{C}$. Tolerance towards $\mathrm{pH}$ as well as requirement for 
and tolerance of sodium ions were tested in $2 \%(\mathrm{w} / \mathrm{v})$ peptone broth [15 g peptone from casein.(Oxoid) and $5 \mathrm{~g}$ soy peptone $(\mathrm{BD}) \mathrm{l}^{-1}$ ] adjusted to $\mathrm{pH} 3-11$ or supplemented with $\mathrm{NaCl}(2,4,6,8,10,12$ and $14 \%$, w/v). To compensate for effects due to osmolarity in the absence of $\mathrm{NaCl}$, the basal medium according to Baumann \& Baumann (1981) was used for inoculation, where $\mathrm{Na}^{+}$is replaced by $\mathrm{K}^{+}$. Growth was observed between $\mathrm{pH} 6$ and 8.5 and at $2-10 \% \mathrm{NaCl}$.

The Gram reaction was determined by addition of $3 \%$ $\mathrm{KOH}$ to a colony grown for 1 day on marine agar (MA; Difco) and by Gram staining. Catalase and oxidase activities were documented by gas production in a $3 \%$ hydrogen peroxide solution and by using Bactident Oxidase test strips (Merck), respectively. Sensitivity towards the vibriostatic agent $\mathrm{O} / 129$ was determined using Oxoid discs (150 mg per disc). Motility was tested on freshly poured MA plates dried for $1 \mathrm{~h}$; swarming of the cells was checked after incubation at $30{ }^{\circ} \mathrm{C}$ overnight. The ability to grow under anaerobic conditions was determined over a 3-day period in an anaerobic jar containing the catalyst Anaerocult IS (Merck), prepared according to the manufacturer's instructions.

API 20NE and API ZYM test strips (bioMérieux) were used to analyse substrate utilization from sole carbon sources, acid production from carbohydrates and enzyme activities. Since misidentification using API systems has been reported when resuspending marine organisms in the solutions provided by the manufacturer (Martinez-Urtaza et al., 2006), the following modifications were introduced to ensure optimal growth conditions. $\mathrm{NaCl}$ was added to a final concentration of $1.5 \%$ to the API $20 \mathrm{NE}$ suspension medium and the AUX solution. Cell suspensions with a standard opacity equivalent to McFarland 3 were used to inoculate the strips, which were incubated for $24 \mathrm{~h}$ at $30{ }^{\circ} \mathrm{C}$ prior to evaluation. For API ZYM, the incubation conditions were modified $\left(6 \mathrm{~h}\right.$ at $30{ }^{\circ} \mathrm{C}$ instead of $4 \mathrm{~h}$ at $\left.37^{\circ} \mathrm{C}\right)$.

Bacteria were grown for $24 \mathrm{~h}$ at $28{ }^{\circ} \mathrm{C}$ on MA to analyse cellular fatty acid composition. Fatty acids were extracted and analysed by the Deutsche Sammlung von Mikroorganismen und Zellkulturen (DSMZ, Braunschweig, Germany) as described previously (Verbarg et al., 2008). Analysis of the fatty acid content showed the predominance of three major fatty acids (Table 1), and the profiles of the novel strains were similar but not identical to those of $V$. rumoiensis DSM $19141^{\mathrm{T}}$ and $V$. litoralis DSM $17657^{\mathrm{T}}$. No significant differences were found between the three new isolates.

The $\mathrm{G}+\mathrm{C}$ content of the genomic DNA was examined by the Identification Service of the DSMZ using HPLC as described by Mesbah \& Whitman (1989). The values obtained were $41.8 \mathrm{~mol} \%$ for WS $4539^{\mathrm{T}}$ and $40.7 \mathrm{~mol} \%$ for WS 4538 and WS 4540.

Table 2 summarizes the phenotypic differences between strain WS $4539^{\mathrm{T}}$ and its two closest phylogenetic relatives.
Table 1. Major fatty acids of the three novel isolates and their closest phylogenetic relatives

Strains: 1 , V. casei sp. nov. WS $4539^{\mathrm{T}}$; 2, V. casei sp. nov. WS 4538; 3, V. casei sp. nov. WS 4540; 4, V. litoralis DSM $17657^{\mathrm{T}} ; 5, V$. rumoiensis DSM $19141^{\mathrm{T}}$. Values are percentages of total fatty acids and were obtained in this study.

\begin{tabular}{|lccccc|}
\hline Fatty acid & $\mathbf{1}$ & $\mathbf{2}$ & $\mathbf{3}$ & $\mathbf{4}$ & $\mathbf{5}$ \\
\hline $16: 1 \omega 7 c$ and/or iso-15:0 2-OH & 41.0 & 41.3 & 40.8 & 43.4 & 40.3 \\
$16: 0$ & 22.0 & 21.2 & 20.4 & 23.9 & 23.2 \\
$18: 1 \omega 7 c$ & 15.6 & 15.9 & 15.4 & 12.0 & 14.0 \\
$14: 03-\mathrm{OH}$ and/or iso-16:1 I & 3.2 & 3.3 & 3.2 & 7.7 & 7.0 \\
$14: 0$ & 1.5 & 1.8 & 1.7 & 1.8 & 4.0 \\
$12: 0$ & 3.8 & 3.8 & 3.6 & 4.0 & 3.8 \\
\hline
\end{tabular}

DNA-DNA hybridization was performed between the strains isolated from smear cheeses and $V$. litoralis DSM $17657^{\mathrm{T}}$ as well as $V$. rumoiensis DSM $19141^{\mathrm{T}}$. The studies were carried out by the Identification Service of the DSMZ based on renaturation curves. DNA was isolated using a French pressure cell (Thermo Spectronic) and purified by chromatography on hydroxyapatite as described by Cashion et al. (1977). Hybridization studies were performed as described by De Ley et al. (1970) with the modifications introduced by Huß et al. (1983), using a model Cary 100 Bio UV/Vis spectrophotometer equipped with a Peltier temperature-controlled $6 \times 6$ multicell changer with an in-situ temperature probe (Varian) in $2 \times$ SSC at $67^{\circ} \mathrm{C}$. Following the recommendations of Wayne et al. (1987), the threshold value of DNA-DNA relatedness is $70 \%$ for the definition of a species. DNADNA hybridization showed that strains WS $4539^{\mathrm{T}}$, WS 4538 and WS 4540 belong to the same species (data not shown). This is also corroborated by the fact that we were unable to find physiological or biochemical differences between the three isolates. DNA pairing of isolate WS $4539^{\mathrm{T}}$ with $V$. litoralis DSM $17657^{\mathrm{T}}$ and $V$. rumoiensis DSM $19141^{\mathrm{T}}$ revealed values for DNA-DNA reassociation

Table 2. Differential phenotypic characteristics of the three novel isolates and their phylogenetically closest relatives

Strains: 1, V. casei sp. nov. WS $4539^{\mathrm{T}} ; 2$, V. litoralis DSM $17657^{\mathrm{T}} ; 3, \mathrm{~V}$. rumoiensis DSM $19141^{\mathrm{T}}$. Data were obtained in this study.

\begin{tabular}{|lccc|}
\hline Characteristic & $\mathbf{1}$ & $\mathbf{2}$ & $\mathbf{3}$ \\
\hline Expression of: & & & \\
$\quad \beta$-Galactosidase & + & - & - \\
$\quad$ Aesculin hydrolase & + & - & + \\
Growth in $12 \% \mathrm{NaCl}$ & - & + & - \\
Growth at $37{ }^{\circ} \mathrm{C}$ & - & + & + \\
Growth at pH 5 & - & + & + \\
Fatty acid content (\%) & & & \\
$14: 0$ & 1.5 & 1.8 & 4.0 \\
$14: 0$ 3-OH and/or iso-16:1 I & 3.2 & 7.7 & 7.0 \\
\hline
\end{tabular}


between 28 and $42 \%$ (Supplementary Table S1, available in IJSEM Online). Therefore, the three strains isolated from the surface of two smear-ripened cheeses constitute a novel species within the genus Vibrio.

The phylogenetic position of the three isolates within the Vibrionaceae was determined by $16 \mathrm{~S}$ rRNA, atpA, recA, $r p o A$ and $p y r H$ gene sequence analyses. Genomic DNA was extracted as described by Wenning et al. (2006). Cyclesequencing PCR of the 16S rRNA gene was performed by Sequiserve (Vaterstetten, Germany) using the 5'-primer $609 \mathrm{~V}$ (5'-GGATTAGATACCCBDGTA-3', corresponding to positions 785-802 in the Escherichia coli 16S rRNA gene) and the $3^{\prime}$-primer 907R (5'-CCGTCAATTCMTTTGAGTTT-3'; positions 907-926). A 1519 bp amplicon revealed the presence of 11 heterogenic positions scattered over the $16 \mathrm{~S}$ rRNA gene, indicating the existence of at least two $r$ rn copies. A sequence similarity of $96.3 \%$ was found to the closest relative, $V$. rumoiensis $\mathrm{S}-1^{\mathrm{T}}$. The sequences were aligned using CLUSTAL_X version 2.09 (Larkin et al., 2007). A rooted phylogenetic tree was calculated according to Kimura's two-parameter model using TREECON version 1.3b (Van de Peer \& De Wachter, 1997) based on $16 \mathrm{~S}$ rRNA gene sequences using the neighbour-joining algorithm (Fig. 1). A bootstrap analysis based on 1000 replicates was performed to test the stability of individual branches (Felsenstein, 1985). As suggested by Thompson et al. (2005), Campylobacter jejuni subsp. jejuni NCTC $11168^{\mathrm{T}}$ was used as an outgroup. The isolates clustered with the clearly separated $V$. rumoiensis group. UPGMA and maximum-likelihood calculations produced the same grouping of the novel isolates (not shown).

Primer sequences and thermal cycling conditions for amplification and sequencing of the atpA, recA, rpoA and pyrH genes were chosen according to Thompson et al. $(2005,2007)$. Phylogenetic trees based on these housekeeping genes supported the status of a novel species and are available in Supplementary Fig. S1.

All three isolates shared a $14 \mathrm{bp}$ insertion in their $16 \mathrm{~S}$ rRNA genes, located between positions 188 and 189 in the E. coli 16S rRNA gene sequence (Cannone et al., 2002; GenBank accession no. J01695). The presence of this fragment in the mature rRNA could be demonstrated by PCR amplification of cDNA samples using the universal primer $27 \mathrm{f}$ and the insertion-specific primer $188 \mathrm{r}$ (for a detailed description, see supplementary material). This insertion results in an elongated structure at helix 10 (calculations carried out using the ARB software; Ludwig et al., 2004) (Supplementary Fig. S2). The insertion further distinguishes the isolates from their closest phylogenetic neighbours and provides a useful tool for quick identification. Such an insertional fragment may move between species through horizontal gene transfer followed by recombination. Among the family Vibrionaceae, comprising 105 species, a 14 or $15 \mathrm{bp}$ fragment was also detected in five other species, which are marked by asterisks in Fig. 1 (see also Supplementary Table S2). Since these species inhabit different environments, the opportunity for horizontal gene transfer must remain speculative.

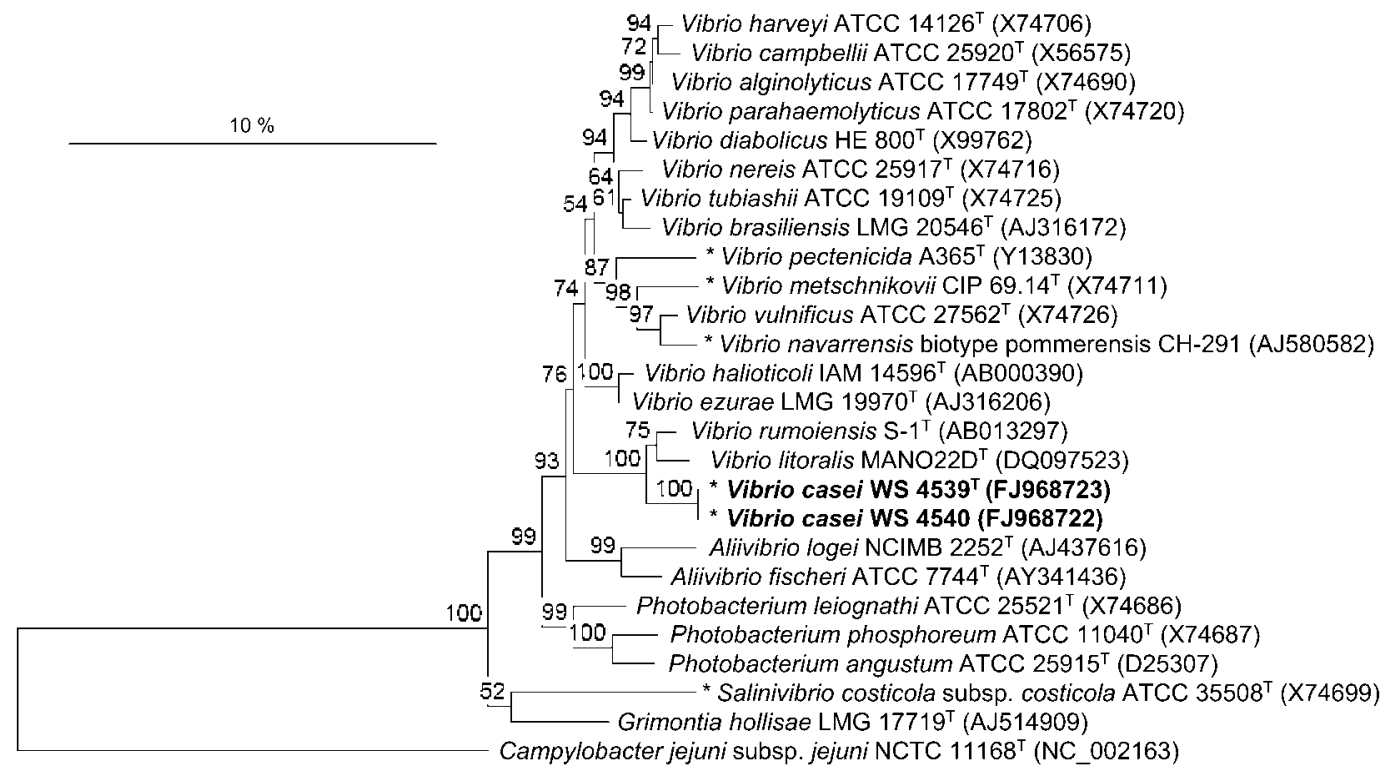

Fig. 1. 16S rRNA gene sequence-based consensus neighbour-joining phylogenetic tree illustrating the position of strains WS $4539^{\top}$ and WS 4540 within the Vibrionaceae. The sequence of Campylobacter jejuni subsp. jejuni NCTC $11168^{\top}$ was chosen as an outgroup. Bootstrap values, expressed as percentages of 1000 replications, are given at branching points. Bar, $10 \%$ sequence divergence. Strains that contain a 14 or 15 bp insert in their $16 \mathrm{~S}$ rRNA gene sequence are marked by asterisks (see text). 
Based on these results, we propose the name Vibrio casei sp. nov. for the novel species. Vibrio sp. R-27449 (GenBank accession no. AJ967016) shares $100 \%$ identity of its $16 \mathrm{~S}$ rRNA gene sequence with $V$. casei sp. nov.; this strain was found by Mounier et al. (2005) on the surface of the Irish smear-ripened cheese Milleens. While this report adds emphasis to the incidence of $V$. casei sp. nov. on cheese surfaces, this isolate was not described as representing a novel species.

\section{Description of Vibrio casei sp. nov.}

Vibrio casei (ca'se.i. L. gen. masc. n. casei of/from cheese, because the first strains were isolated from the surfaces of smear-ripened cheeses).

Cells are Gram-negative, straight rods, $0.6-1.2 \mu \mathrm{m}$ wide and $1.5-1.8 \mu \mathrm{m}$ long. Colonies grown aerobically on MA are cream, smooth, round or slightly irregular in shape and $1-2 \mathrm{~mm}$ in diameter after 3 days of culture at $30^{\circ} \mathrm{C}$. Growth occurs at $2-30{ }^{\circ} \mathrm{C}$ and $\mathrm{pH} 6-8.5$. Isolates require sodium ions and grow in the presence of $2-10 \% \mathrm{NaCl}$. Motile but not swarming. Bioluminescence is not observed. Susceptible to the vibriostatic agent O/129. Catalase- and oxidase-positive. Facultatively anaerobic. Nitrate is reduced to nitrite. The following substrates can be utilized as sole energy and carbon sources: glucose, arabinose, mannose, mannitol, $\mathrm{N}$-acetylglucosamine, maltose, gluconate, malate and citrate. $\beta$-Galactosidase, aesculin hydrolase, alkaline phosphatase, acid phosphatase, esterase (C4), esterase lipase (C8), leucine arylamidase, naphthol-AS-BI-phosphohydrolase and $N$-acetyl- $\beta$-glucosaminidase activities are present. The predominant fatty acids are $16: 1 \omega 7 c$

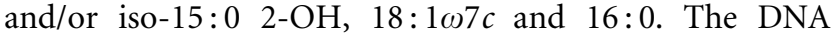
$\mathrm{G}+\mathrm{C}$ content of the type strain is $41.8 \mathrm{~mol} \%$.

The type strain, WS $4539^{\mathrm{T}}\left(=\mathrm{DSM} 22364^{\mathrm{T}}=\mathrm{LMG} 25240^{\mathrm{T}}\right.$ ) was isolated from the surface of Petit Munster cheese from the Fromagerie de l'Ermitage, Bulgnéville, France. The reference strain WS 4540 (=DSM $22378=$ LMG 25241) was isolated from the surface of Petit Livarot cheese at Les Fromages de Tradition, Mondeville, France.

\section{Acknowledgements}

This study received research funding from the European Community's Sixth Framework Programme. TRUEFOOD (Traditional United European Food) is an Integrated Project financed by the European Commission under the 6th Framework Programme for RTD (contract number FOOD-CT-2006-016264). The information in this document reflects only the authors' views and the Community is not liable for any use that may be made of the information contained herein. We are grateful to Professor Dr Hans Georg Trüper from the IFMB, University of Bonn, for his expert suggestions concerning nomenclature and to $\mathrm{Dr}$ Wolfgang Ludwig, Chair of Microbiology, Technical University of Munich, for his kind provision of the rRNA secondary structures.

\section{References}

Baumann, P. \& Baumann, L. (1981). The marine gram-negative eubacteria: genera Photobacterium, Beneckea, Alteromonas,
Pseudomonas, and Alcaligenes. In The Prokaryotes. A Handbook on Habitats, Isolation and Identification of Bacteria, pp. 1302-1331. Edited by M. P. Starr, H. Stolp, H. G. Trüper, A. Balows \& H. G. Schlegel. New York: Springer.

Baumann, P. \& Baumann, L. (1984). Genus II. Photobacterium Beijerinck 1889, 401 ${ }^{\mathrm{AL}}$. In Bergey's Manual of Systematic Bacteriology, vol. 1, pp. 539-545. Edited by N. R. Krieg \& J. G. Holt. Baltimore: Williams \& Wilkins.

Baumann, P. \& Schubert, R. H. W. (1984). Genus II. Vibrionaceae Veron 1965, 5245 ${ }^{\mathrm{AL}}$. In Bergey's Manual of Systematic Bacteriology, vol. 1, pp. 516-517. Edited by N. R. Krieg \& J. G. Holt. Baltimore: Williams \& Wilkins.

Browne-Silva, J. \& Nishiguchi, M. K. (2008). Gene sequences of the pil operon reveal relationships between symbiotic strains of Vibrio fischeri. Int J Syst Evol Microbiol 58, 1292-1299.

Cannone, J. J., Subramanian, S., Schnare, M. N., Collett, J. R., D’Souza, L. M., Du, Y., Feng, B., Lin, N., Madabusi, L. V. \& other authors (2002). The comparative RNA web (CRW) site: an online database of comparative sequence and structure information for ribosomal, intron, and other RNAs. BMC Bioinformatics 3, 2.

Cashion, P., Holder-Franklin, M. A., McCully, J. \& Franklin, M. (1977). A rapid method for the base ratio determination of bacterial DNA. Anal Biochem 81, 461-466.

De Ley, J., Cattoir, H. \& Reynaerts, A. (1970). The quantitative measurement of DNA hybridization from renaturation rates. Eur $J$ Biochem 12, 133-142.

El-Baradei, G., Delacroix-Buchet, A. \& Ogier, J. C. (2007). Biodiversity of bacterial ecosystems in traditional Egyptian Domiati cheese. Appl Environ Microbiol 73, 1248-1255.

Felsenstein, J. (1985). Confidence limits on phylogenies: an approach using the bootstrap. Evolution 39, 783-791.

Feurer, C., Irlinger, F., Spinnler, H. E., Glaser, P. \& Vallaeys, T. (2004). Assessment of the rind microbial diversity in a farmhouseproduced vs a pasteurized industrially produced soft red-smear cheese using both cultivation and rDNA-based methods. J Appl Microbiol 97, 546-556.

Huß, V. A. R., Festl, H. \& Schleifer, K. H. (1983). Studies on the spectrophotometric determination of DNA hybridization from renaturation rates. Syst Appl Microbiol 4, 184-192.

Kümmerle, M., Scherer, S. \& Seiler, H. (1998). Rapid and reliable identification of food-borne yeasts by Fourier-transform infrared spectroscopy. Appl Environ Microbiol 64, 2207-2214.

Larkin, M. A., Blackshields, G., Brown, N. P., Chenna, R., McGettigan, P. A., McWilliam, H., Valentin, F., Wallace, I. M., Wilm, A. \& other authors (2007). CLUSTAL W and CLUSTAL_X version 2.0. Bioinformatics 23, 2947-2948.

Ludwig, W., Strunk, O., Westram, R., Richter, L., Meier, H., Yadhukumar, Buchner, A., Lai, T., Steppi, S. \& other authors (2004). ARB: a software environment for sequence data. Nucleic Acids Res 32, 1363-1371.

Martinez-Urtaza, J., Lozano-Leon, A., Vina-Feas, A., de Novoa, J. \& Garcia-Martin, O. (2006). Differences in the API 20E biochemical patterns of clinical and environmental Vibrio parahaemolyticus isolates. FEMS Microbiol Lett 255, 75-81.

Mellado, E., Moore, E. R., Nieto, J. J. \& Ventosa, A. (1996). Analysis of $16 \mathrm{~S}$ rRNA gene sequences of Vibrio costicola strains: description of Salinivibrio costicola gen. nov., comb. nov. Int J Syst Bacteriol 46, 817821.

Mesbah, M. \& Whitman, W. B. (1989). Measurement of deoxyguanosine/thymidine ratios in complex mixtures by high-performance liquid chromatography for determination of the mole percentage guanine + cytosine of DNA. J Chromatogr 479, 297-306. 
Mounier, J., Gelsomino, R., Goerges, S., Vancanneyt, M., Vandemeulebroecke, K., Hoste, B., Scherer, S., Swings, J., Fitzgerald, G. F. \& Cogan, T. M. (2005). Surface microflora of four smear-ripened cheeses. Appl Environ Microbiol 71, 6489-6500.

Nam, Y. D., Chang, H. W., Park, J. R., Kwon, H. Y., Quan, Z. X., Park, Y. H., Kim, B. C. \& Bae, J. W. (2007). Vibrio litoralis sp. nov., isolated from a Yellow Sea tidal flat in Korea. Int J Syst Evol Microbiol 57, 562-565.

Naumann, D., Helm, D. \& Labischinski, H. (1991). Microbiological characterizations by FT-IR spectroscopy. Nature 351, 81-82.

Thompson, F. L., lida, T. \& Swings, J. (2004). Biodiversity of vibrios. Microbiol Mol Biol Rev 68, 403-431.

Thompson, F. L., Gevers, D., Thompson, C. C., Dawyndt, P., Naser, S., Hoste, B., Munn, C. B. \& Swings, J. (2005). Phylogeny and molecular identification of vibrios on the basis of multilocus sequence analysis. Appl Environ Microbiol 71, 5107-5115.

Thompson, C. C., Thompson, F. L., Vicente, A. C. P. \& Swings, J. (2007). Phylogenetic analysis of vibrios and related species by means of atpA gene sequences. Int J Syst Evol Microbiol 57, 2480-2484.

Van de Peer, Y. \& De Wachter, R. (1997). Construction of evolutionary distance trees with TREECON for Windows: accounting for variation in nucleotide substitution rate among sites. Comput Appl Biosci 13, 227-230.

Verbarg, S., Frühling, A., Cousin, S., Brambilla, E., Gronow, S., Lünsdorf, H. \& Stackebrandt, E. (2008). Biostraticola tofi gen. nov., spec. nov., a novel member of the family Enterobacteriaceae. Curr Microbiol 56, 603-608.

Wayne, L. G., Brenner, D. J., Colwell, R. R., Grimont, P. A. D., Kandler, O., Krichevsky, M. I., Moore, L. H., Moore, W. E. C., Murray, R. G. E. \& other authors (1987). International Committee on Systematic Bacteriology. Report of the ad hoc committee on reconciliation of approaches to bacterial systematics. Int J Syst Bacteriol 37, 463464.

Wenning, M., Theilmann, V. \& Scherer, S. (2006). Rapid analysis of two food-borne microbial communities at the species level by Fourier-transform infrared microspectroscopy. Environ Microbiol 8, 848-857.

Yumoto, I. I., Iwata, H., Sawabe, T., Ueno, K., Ichise, N., Matsuyama, H., Okuyama, H. \& Kawasaki, K. (1999). Characterization of a facultatively psychrophilic bacterium, Vibrio rumoiensis sp. nov., that exhibits high catalase activity. Appl Environ Microbiol 65, 67-72. 